\title{
ALUMiniUm AND CONTEMPORARY AUSTRALIAN DESIGN: MATERIALS HiSTORY, CULTURAL AND NATIONAL IDENTITY.
}

\author{
SUZETTE WORDEN \\ s.worden@curtin.edu.au \\ Curtin University of Technology, Perth, Western Australia
}

\begin{abstract}
This article examines the significance of aluminium for Australian design. It provides an overview of aluminium within the Australian resource economy and then documents the uses of aluminium across a range of design sectors, including engineering design, furniture, product design and crafts production. This engagement with a broad view of design is presented as a validation of the potential of 'materials' histories to contribute to an understanding of design across production and consumption.

The period 1990 to 2007 is examined in detail to show how aluminium was included in discussions of regional and national identity. Also noted is how the cultural values attributed to aluminium are relevant for an understanding of the international promotion of Australian design and crafts and the positioning of Australian designers within the creative industries. Finally, evidence of the appreciation of aluminium for recycling, within the context of sustainability and innovation, provides a broader view of design within consumption and as an outcome of design research.
\end{abstract}

\section{KEYWORDS}

Aluminium, Australia, Bruno Latour, materiality, national identity, resource economy.

\section{AUTHOR'S FINAL DRAFT}

Worden, Suzette. 2009. Aluminium and Contemporary Australian Design: Materials History, Cultural and National Identity. Journal of Design History 22 (2): pp. 151-171. 


\section{ALUMINIUM AND CONTEMPORARY AUSTRALIAN DESIGN: MATERIALS History, CULTURAL AND NATIONAL IDENTITY.}

INTRODUCTION

Current histories of Australian design document a design sensibility that has arisen out of a colonial past and a fast-paced, but restricted, entry into manufacturing during the 20th century. ${ }^{1}$ These texts have included 'internal' histories of individual and group achievements, ${ }^{2}$ discussions of appropriation of indigenous culture, ${ }^{3}$ cultural and national identity ${ }^{4}$ and documentation of 'external' relations within global industrial contexts. ${ }^{5}$ These accounts have often shown that disjointed relationships have existed between Australian design and equivalent activities globally. Additionally, European interpretative schemas have not always been considered to be easily transferable to Australian conditions. ${ }^{6}$

This article proposes that a study of aluminium, in the context of Australian design production, promotion and consumption, can extend current discussions of how Australian design fits into a wider global economy. This study of aluminium will also contribute to discussions of the formation of Australian cultural and national identity through design, and documents both individual and group achievements.

Examples of Australian design using aluminium can be found in a variety of products ranging from the precious to the ubiquitous, from ships to furniture to cans and jewellery and from mass-production to craft production. In the context of consumption, aluminium products, such as saucepans and other items of kitchenware, foil and cans for packaging, became increasingly common-place during the 20th century. Since the 1980s, designers and makers have explored individualised symbolic languages in the design of furniture, lighting and jewellery using aluminium. The objects produced have been used in design promotion to symbolise a 'sense of place' and as a projection of cultural and national identity within export markets.

In this article, examples of the production and uses of aluminium from engineering and mass production, sustainable design, product design and the crafts will be used to discuss materials more generally as a focus for design history. This article therefore poses two related questions: Can histories of materials show networks and relationships between resources, the technical, objects, social activities and cultural meaning? What potential is there for histories of materials to provide new areas of research for design history?

\section{CONTEXT}

Australian design has displayed many of the same concerns about industrialisation and consumerism as other major industrialised countries, but in addition there is the legacy of its colonial past. Discussions of national identity have included consideration of the influence of 19th century colonial 'settler society', which displaced 'history' and created the idea of an 'Indigenous non-relationship with the land'. ${ }^{7}$ Identity 'myths' have been created through design, as for example inventiveness in relation to the bicentennial celebrations of 1988. As Simon Jackson has observed, these images of national identity 
were celebratory in the popular press and the design industry was uncritical or selfserving. ${ }^{8}$

Closely linked to the history of Australia within the British Commonwealth and Empire is the extent to which Australia's contribution to the global economy has been tied to the exploitation of its natural resources. ${ }^{9}$ This has included the production of agricultural products such as timber, wool, and wheat. Mining industries have included gold, coal, aluminium and, more recently, iron ore and natural gas. In examining the significance of aluminium for design, a further question asked in this article is what connections can be traced between an important Australian resource (alumina), which is transformed into a material (aluminium) and then to 'design' as a material object (as practice and as things)? Relationships can be traced across manufacture and consumption; for example schemes encouraging consumers to recycle cans. Connections are also culturally defined, however, and as this article shows there have been various initiatives for design promotion where symbolically connecting aluminium objects to cultural and/or national identity has been central to their promotional aims.

Although this article discusses aluminium in the context of Australian design, both generally for the late 20th century and more specifically for the period 1990 to 2006, a discussion of its significance within economic and cultural exchange will provide the groundwork for international comparison. Also, histories of materials are needed to inform studies concentrating on the 'immaterial' in global information and knowledge economies of the late 20th and early 21st century. Modernism had a materialist ethic that was eventually demolished by new technologies. Those new technologies such as plastics and automation, but particularly computerisation, have led to concern for virtuality and the ephemeral. But, as Abram Moles has suggested, these technologies cannot exist unless these immaterial products are linked to the material and mechanical infrastructure that generates, stabilises and governs them. ${ }^{10}$

\section{MATERIALS HISTORIES}

The subject of materials in relation to design has received uneven treatment but attention to materials can nevertheless be found in design-related sources spanning the crafts and applied arts through to the history of technology. In the craft and applied arts areas of design, which derive methodologies from connoisseurship, it is common to get histories of artefacts grouped together within materials: wood, clay, iron, bronze, silver and gold, etc. The categorisation of objects by their material, as artificial or natural, is prevalent in museum classification and underlies the categorisation of, and distinction between, museums of fine art, applied art, natural history and social history. There is also a hierarchy of prestige and value attributed to these categories, as a consequence of the fine arts acquiring a higher status during the 18th and 19th centuries. ${ }^{11}$ In addition to materials taxonomies, an appreciation of materials in these contexts can be related to the spectator's response to technical virtuosity: 'the viewer's wonder at the process of making, of the transformation from nature to art'.12 Understanding the attributed values provides a connection between production and consumption. For the production of objects, this is relevant where materials have qualities that designers use and exploit. Not only do designers manipulate a material's strength, look, feel, or durability but they also manipulate associated meanings that evoke cultural associations.

Design historians have integrated concepts and methods from material culture into their research process. Although this has provided new ways of interpreting and understanding objects, materials are less integral to this way of studying design and the word 'material' is used to describe the more collective physical/virtual and social world 
of objects, collections and systems. ${ }^{13}$ These objects, as distinct from representations, can be natural or manufactured; they carry values and have a physical presence. ${ }^{14}$ The primary interest within the study of material culture is to examine the social and symbolic value of things. This has been especially important for design historians where they have concentrated on investigating everyday things and the consumption of objects. ${ }^{15}$ One useful outcome of this approach has been the breaking down of hierarchies of value in terms of what objects are worthy of investigation. This suggests that all things are worth investigating in intellectual projects that provide a constructed view of the materiality of objects, where objects both reflect and change social relations. The choice of what is studied, of what matters however, is constructed through the process of authorship and the process whereby objects can be seen to change social conditions. This has been welcomed as a positive move to break down the idea that design outcomes were mostly the work of professional designers.

For material culture studies, which draw on archaeology as well as anthropology, materials science has played a further role in providing evidence about 'things'. This analytical approach is based on making explicit the 'structure' of an object; 'how the component parts of an object are arranged and how their interactions result in particular properties'.16 This approach is considered most helpful for the analysis of objects as tools or instruments but is limited in contributing to cultural and semiotic meaning.

Even though materials are regarded as a determining factor in the history of modern design, interest in materials is most often integrated with other considerations, rather than be singled out,. Dennis Doordan has summarised the challenges facing the researcher of materials by suggesting that any framework for the study of materials should consider the triad 'fabrication', 'application' and 'appreciation'. He described these as 'placements' as opposed to categories. ${ }^{17}$ The work of the designer in the feedback loops within that sequence should also be considered. Doordan also warned against a positivist approach where new materials might be seen to 'naturally' generate new formal languages for design. ${ }^{18}$

As part of fabrication, materials are associated with technology; but technology as a descriptive term has been shown to be a recent invention, an ambiguous word. ${ }^{19}$ In its broadest terms it can encompass knowledge and be an activity, a specific activity of design or an object. ${ }^{20}$ Historians of technology have generally recognised that technologies are part of cultural practice and that every technology is 'embedded in a continual (re)construction of the world'. ${ }^{21}$ This embeddedness is most apparent from Science Technology Studies, in particular Actor-Network-Theory (ANT).

Bruno Latour, who has provided a theoretical overview of ANT, has expressed similar concerns over technological determinism, where he notes the poverty in approaches that overemphasise the technical. He also suggests that an overemphasis on the social as a mirror reflecting social distinctions or as a backdrop for social actors is equally problematic. ${ }^{22}$ For Latour objects have agency and a multiplicity; their visibility is relevant for defining the social. In this context the term material culture is not satisfactory if it means that objects are understood to be connected to one another only within their own realm. In his development of ANT, Latour suggests being open-minded about the difference between material causality and human action and recognising the multiplicity of objects. ${ }^{23}$ Latour prefers to discuss a 'flattening' of the landscape, which is useful for an investigation of materials. In his disassembling of both the social and nature, he emphasises the need to extend the theory to 'natural' objects, which could include materials, stating that it is harder to show that 'nature' when it is 'conceived as the gathering of all non-social matters of fact should be dispensed with as well'. ${ }^{24}$ The social and the natural have to be dissolved simultaneously. As Latour has noted: 
ANT is not interested only in freeing human actors from the prison of the social but in offering natural objects an occasion to escape the narrow cell given to matters of fact by the first empiricism. ${ }^{25}$

This is a useful approach as it allows aspects of production, and for 'natural' objects to be incorporated into networks that can also be extended across consumption. ${ }^{26}$ Objects become performative and integrative. The constructive capacities of both have been clearly recognised by ANT researchers. For example, Wanda Orlikowski has suggested that it is useful to recognise how the power of 'human agency' and 'material performativity' help us to recognise the power of both without equating them. ${ }^{27}$ This approach, shared by other researchers in the field of Science Technology Studies, is useful because it enables an interpretation of design where the relationships emerge from the analysis and there is no fixed expectation that materials will be the 'background' for 'culture'. In this view, material performances and human agencies are both implicated in the other (human agency is always materially performed, just as material performances are always enacted by human agency).

These different approaches are often accompanied by a slippage in terminology, where material is stuff, what an object is made of, or a collective term for artefacts. The associated term of materiality is used to define a presence, a quality or a social process. For example, within the realm of explaining creative research for the arts, architecture and design, Paul Carter has described 'material thinking' as 'an intellectual adventure peculiar to the making process' where the 'creative intelligence of materials' is connected with self-realisation in creative research. ${ }^{28}$ Each of these uses of the word material has its own integrity and context but at the same time the variety of contexts and meanings of material show a proliferation of ideas and concepts across material as a resource, an object or as culturally defined.

In the following discussion, one task is to reveal the connections, networks and fractures across production, consumption and reception. For aluminium, this suggests exploring the balance between aluminium being the 'stuff' that comes from 'nature', is part of technology and production and is a material providing opportunities for innovation and being read as a sign. The discussion will focus on the following questions: Does

aluminium have a special meaning within Australian cultural and national identity? How does this relate to 'sense of place' and perceptions of the global and the local? What kind of agency do the designers have when they design artefacts using aluminium? What is their contribution to product innovation, symbolic language and national identity?

\section{ALUMINIUM: AN INTERNATIONAL HISTORY}

Although aluminium has become an essential component of everyday life, it has never overwhelmed the design landscape; instead aluminium became associated, through the 20th century, with multiple attributes including preciousness, versatility, economy, strength and lightness. In the 20th century aluminium failed, unlike plastics, to pass itself off as a substitute material. When accepted on its own terms, aluminium acquired a reputation based on its aesthetic neutrality and also became popular for its malleability, ability to be recycled ${ }^{29}$ and potential to be transformed through printing and colouring. It naturally generates a protective oxide coating which can be improved by other surface treatments so that it can be used as a low maintenance structural material.

As an almost 'invisible' taken-for-granted part of our material culture, its use in the manufacture of planes, trains and boats, bicycles, electronic components and food preservation is essential for 21st century living. In these varied uses, its lightness is valued as it has a density of a third that of steel and its use can save energy consumption. 
Its strength can be modified through the composition of its alloys. In manufacture it can be cast, formed and machined like most other metals. It is impermeable and odourless when rolled to thin layers so is useful for packaging of food and pharmaceuticals. ${ }^{30}$ Designers and manufactures have exploited these qualities in many innovative and socially useful ways. The catalogue Aluminum by Design: Jewelry to Jets, from an international exhibition curated by Sarah Nichols at the Carnegie Museum of Art, has provided several approaches for considering this important material for a wide variety of products, and the authors discuss the application of aluminium in the context of shifting social, political and economic contexts. ${ }^{31}$

From a history of technology perspective, Eric Schatzberg's contribution to the history of aluminium has been to examine the contradictory meanings associated with aluminium and link the concept of culture with the business history of technological innovation. ${ }^{32}$ He examined aviation, electrical wiring and automobile bodies in detail to discuss the rhetoric of enthusiasm and aluminium's symbolic association with modernisation and the ideology of technological progress. This is shown through its association with transport. It was symbolically associated with flight long before it became used in aircraft production. Within this context, the meaning of aluminium for aviation was, however, 'always in relation to competing industrial materials' 33 and aluminium has by its very success in mundane applications 'helped undermine its symbolism as the metal of the future.' ${ }^{34}$ Similarly Clive Edwards has shown that the use of aluminium for furniture could either be hidden or be an innovative and modern design statement. ${ }^{35}$

From the beginning of the 20th century the uses of aluminium for the domestic market were first appreciated for the metals functionality in cookware and then in fashionable household objects. ${ }^{36}$ Diversification within the aluminium industry after the Second World War led to its promotion for the manufacture of consumer goods, thereby extending its use in manufacture. It is still being 'reinvented' for innovative use in both familiar and new contexts. A recent example for the automobile industry is the collaboration between Alcoa (USA) and Audi, with the Audi A2 launched in 1999. The aim of this collaboration was to produce a lighter, more fuel efficient car that was therefore considered more environmentally friendly. ${ }^{37}$

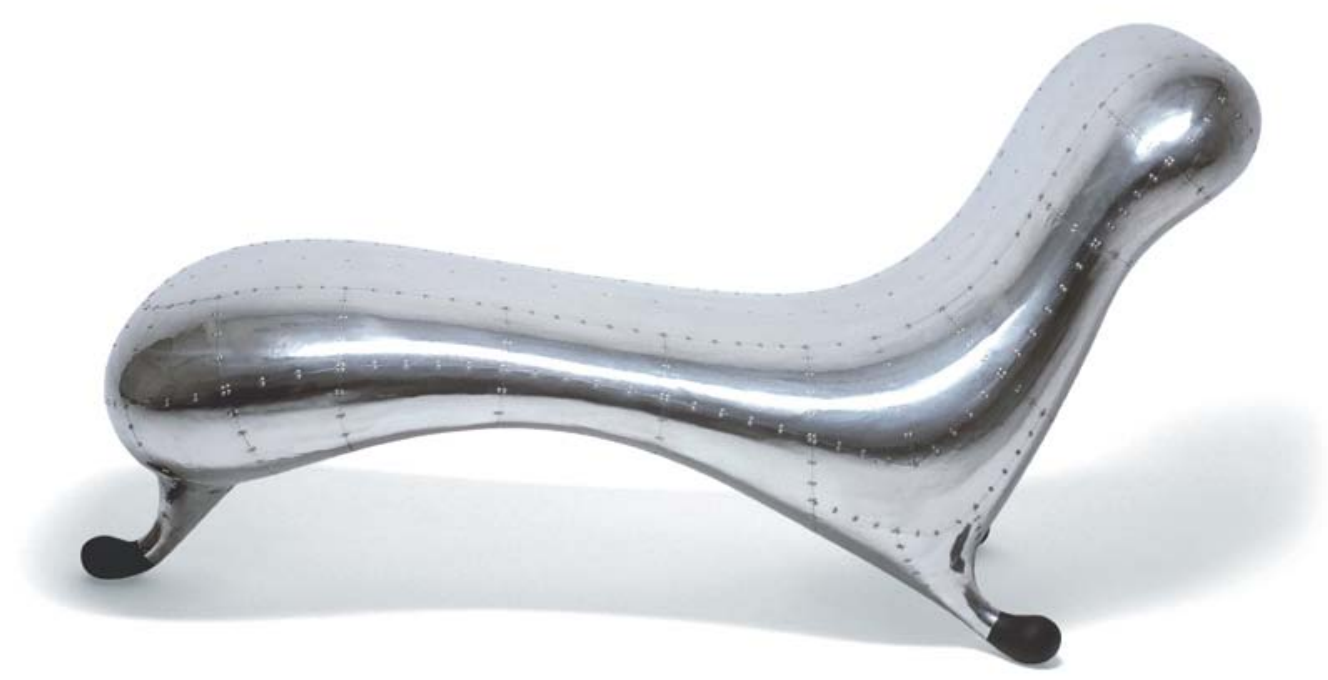

[1] Lockheed Lounge chair, designed by Marc Newson and launched in 1986.Reproduced with permission from Marc Newson Ltd. 
Aluminium has continued to have contradictory appeal. Many of its uses over the last twenty-five years have indicated that its value as a material for precious, refined objects has been exploited by designers to gain a marketing advantage. Marc Newson's 'Lockheed Lounge' chair, launched in 1986, became his design signature in this way [1]. In a global market, the use of aluminium for its sleek and refined finish has been a feature of designs for Apple computers. In 2003, Jonathan Ive and the Apple design team gave the Macintosh PowerBook G4 and PowerMac G5, with their anodised aluminium alloy cases, a sophisticated image of simplicity that distanced the Apple design from that of other computers. ${ }^{38}$ At the same time aluminium has been a material that has proven use in and further potential for sustainable products and so has been considered within ecodesign initiatives. ${ }^{39}$

This article will now explore this contrast between preciousness and ubiquity in more detail within Australian design, first, by considering resource production and materials manufacture and then by considering a range of products from industrial design, domestic products, to crafts, sculpture and associated promotional contexts. These promotional contexts include Australian Government policy documents, sculpture competitions run by an aluminium manufacturing company and exhibitions promoting Australian design for Australian and international audiences.

\section{Aluminium In THE Australian RESOURCE ECONOMY}

Aluminium production grew to become an important part of the late 20th century Australian economy. In 2005, Australia produced 34\% of the world's bauxite and was the largest producer and exporter of alumina, producing $30 \%$ of the world's alumina. In the same year Australia was the fifth largest aluminium producer, providing $6 \%$ of world aluminium production. ${ }^{40}$

The mining of bauxite first began at Weipa in Queensland in 1961, then in the Darling Range in Western Australia from 1963 and Gove in Northern Territory from 1971. By 1963 , the annual production of bauxite was two million tonnes, which rose to 45 million tonnes in 1998. ${ }^{41}$ Alumina refineries were developed at Gladstone in Queensland and Kwinana, Pinjarra, Wagerup and Worsley in Western Australia. Production of alumina amounted to three million tonnes in 1972, rising to 14.1 million tonnes in 1998-9. At that stage it had reached $30 \%$ of world production. These refineries developed with low cost energy supplies and became some of the largest, and as a consequence, the most efficient refineries in the world, with $80 \%$ of production being exported in 1998-9.42

Aluminium was first commercially produced in Australia at Bell Bay, Tasmania in 1955 and was dependent on imported supplies of bauxite. The Port Henry smelter in Victoria was opened in 1963 to take advantage of Australian supplies of bauxite. A further smelter, the Portland smelter, was opened in Victoria in 1987. In Queensland, the Kurri Kurri smelter started operating in 1967 and the Tomago smelter in 1983. The Queensland smelter at Boyne Island started in 1982.43 Smelting is an energy intensiveprocess with electricity accounting for $21 \%$ of costs. ${ }^{44}$

The industry is one of the few in the Australian resources sector to have become dominated by value-added exports (alumina, ingot, and semi-fabricated products) and many of the world's leading aluminium companies participate in the Australian industry. ${ }^{45}$ Semi-fabrication processes have been built up to include rolling and extrusion, producing plate, sheet, foil or a variety of extruded shapes. By 2001 the Australian Government's Light Metals Action Agenda (LMAA) report described a mature 
domestic market that needed to be more environmentally aware and an industry that needed to improve its record for sustainability at the same time as encouraging a greater uptake of aluminium by end users. ${ }^{46}$ Further industrial development was seen to include adopting various strategies concerning investment, energy (including greenhouse gas emissions), industry leadership, market development, innovation and sustainable development. Connections were being traced through the industry's supply chain, with the objective of improving the linkages between technological development and end users. This included identifying end-users, which meant not just influencing consumers but also designers and architects. The LMAA report recognised that the industry should have closer links with designers through their design associations and their education and training. ${ }^{47}$

\section{ALUMINIUM AND AUSTRALIAN DESIGN}

The aluminium industry has always had to operate at an international level owing to high set-up costs. Designers have exploited its qualities in products for local and international markets and, as noted by Edwards, in an account of aluminium furniture produced up until the mid-1980s, the association of aluminium companies with national identities has been limited. ${ }^{48}$ Nonetheless, examples of Australian design using aluminium have been used to project an Australian design sensibility from the late 1980s onwards, both in design promotion based on the marketing of national identity and for association with 'sense of place'. There are examples of this symbolic meaning associated with aluminium, alongside the use of aluminium for its physical attributes such as lightness, durability and re-use; in objects large and small from ship building to packaging.

\section{Engineering, Structural and Product Design}

As already noted, aluminium has always been important for transport design. The extent to which the resource (alumina) material (aluminium) can be traced to a design or material object (as practice and as things) is shown by an account of the A380 aircraft, the world's largest passenger aircraft. The production of the aircraft involved 18,000 suppliers in 30 countries. When reporting the manufacture of the A380 airbus in 2005, an American news reporter summarised a supply chain which started near Perth, Western Australia, where bauxite ore was mined and where refineries produced alumina. This alumina was then shipped to a smelting plant in Texas and used in the production of aluminium ingots. These were shipped to an Alcoa milling plant in Davenport, Iowa. The article went on to describe the scale of the production of the aircraft, including the transportation of larger components across the world for assembly in France. In this context, Australian alumina was identified as part of a supply chain within the global economy. 49

One achievement was the construction in Australia by Austal of what is still, in 2007, the world's biggest aluminium ship. The 127-metre trimaran fast ferry the 'Benchijigua Express', was built in Henderson, Western Australia for Fred Olsen S.A. [2]. In 2005 the trimaran was delivered to the Canary Islands for ferry services in that locality. ${ }^{50}$ The ferry attracted interest as the new design claimed to offer a smoother journey for the ferry passengers. Austal acquired the company Oceanfast Yachts in 1999. This company, also based in Henderson, was established in 1984. One of its most notable designs was the 'Aussie Rules' 69.5 metre aluminium-hulled luxury motor yacht, built in 2002, for golfing professional Greg Norman, which was designed by N.I. Designs in association 
with Sam Sorgiovanni and Design Works [3].51 These were notable achievements in a specialist international market.

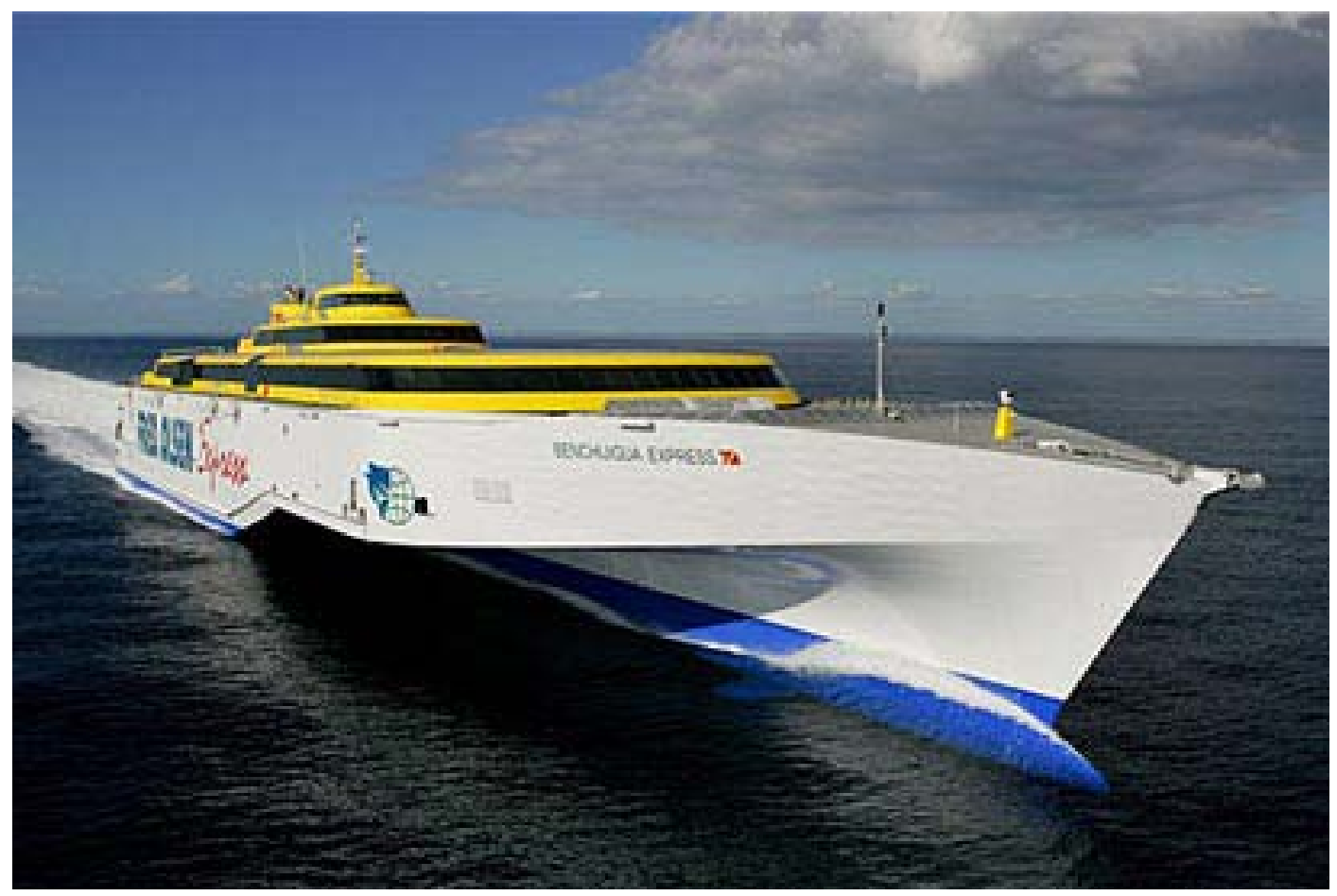

[2] The 'Benchijigua Express' Trimaran built by Austal, Henderson, Western Australia, 2005. Photograph copyright Austal. Photograph courtesy of Austal, Australia, 2009.

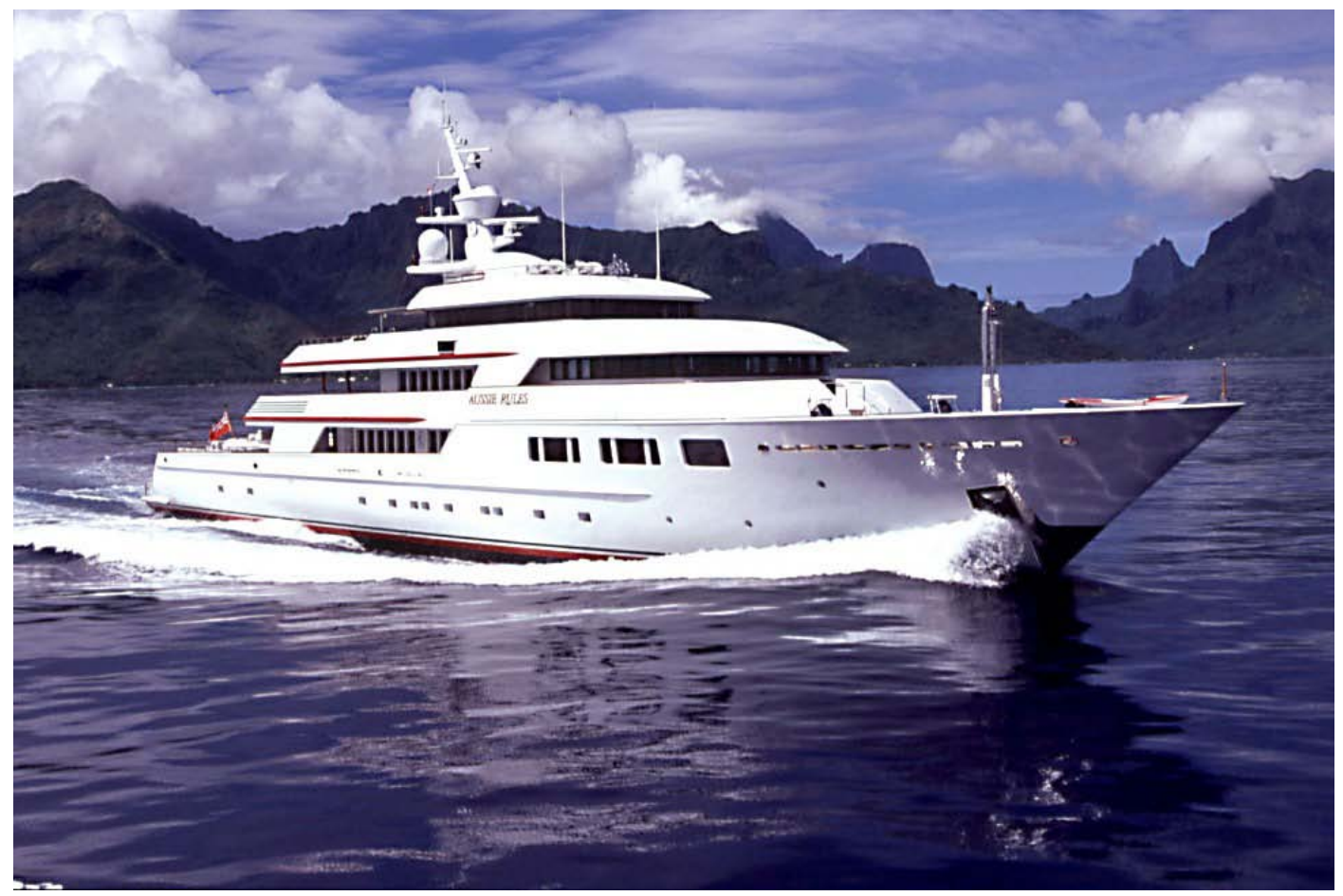

[3] MY 'Aussie Rules' luxury motor yacht, built by Austal, Henderson, Western Australia, 2002. (Oceanfast) MY Aussis Rules, Picture courtesy of Oceanfast. 
These examples of transport design are for specialist markets operating alongside the use of aluminium in the production of consumer products that merge into the built environment. The aluminium window frame is one such product; the use of aluminium for cookware, and household goods and packaging were others. Comalco Castalloy, an Adelaide die-cast firm, was established in 1948 and produced castings for familiar Australian products such as the Hills Hoist rotary clothesline, Victa motor mower chassis and aluminium cookware. In 1955 their range extended to include parts for the motor industry. In 1985, Castalloy was active in international markets and began producing light alloy parts and wheels in association with the US motor bike company Harley Davidson. ${ }^{52}$

\section{MODERN DESIGN}

Aluminium was a material that Australian designers used successfully in products with distinctive formal qualities. For Gordon Andrews (1914-2001), designs using aluminium contributed positively to his reputation as an as innovative modern designer. He valued skills and sensitivity. His philosophy was typical of those promoting 'Good Design' which he saw as:

the result of a conscious act of bringing order and grace to a product so as to imbue it with aesthetic qualities beyond, but including, the purely functional. 53

In the 1950s, Andrews was bringing European experiences back to Australia. He worked in Britain from 1937 to 1939, and again from 1950 but returned to Australia in 1956. ${ }^{54}$ He used aluminium in his 'Gazelle' chair of 1956, which had a curved oval seat and an oval backrest, supported by three tapered aluminium legs [4]. This was an update of an earlier design, of 1950, for an Olivetti showroom in London. The earlier design had four tapered wooden legs. In 1956, Andrews also designed the 'Rondo' easy chair, which also had aluminium legs. These designs have similar features to those designed around the same time by Charles Eames for Hermann Miller and Ernest Race for Ernest Race Ltd. In Australia, Andrews found that, as well as being the designer, he also had to become a contractor, organising the production of the chairs in batches as no manufacturer would take on Australian designs; they would rather import Scandinavian, Italian and American furniture. ${ }^{55} \mathrm{He}$ therefore found it difficult to introduce new designs to the Australian market.

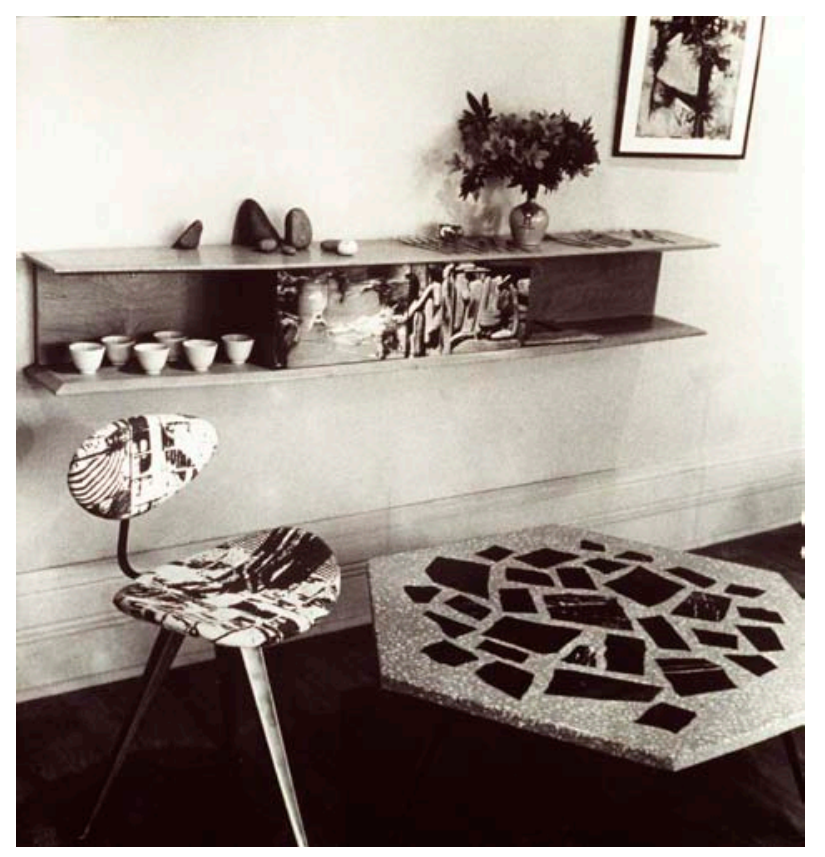

[4] Gazelle chair, designed in 1956 by Gordon Andrews. Photograph, Andrews Designs Pty Ltd showroom, 57-59 Macleay Street, Potts Point, Sydney, mid-1950s. Reproduced with permission from Mary Andrews. Collection: Powerhouse Museum, Sydney, 89/735-39/18.

The use of aluminium as a modern material was reinforced in by the company Comalco through a sculpture competition which was set up in 1968. The competition was a response to designing for the expanding urban environment, and annually, for four years, six sculptors entering the competition were awarded a grant and asked to develop works for specific architectural environments. Some of the entries 
were subsequently commissioned. In 1968, Vincas Jomantas designed a screen for the new Australian Embassy in Washington. Margel Hinder won the competion in 1969 with a sculpture for the new town centre of Woden, Canberra, and in 1970 John Davis was awarded the prize for a large wall piece for the Tasmanian Hydro-Electric Commission. By 1971, the competition had established itself for its abstract works fabricated in aluminium. ${ }^{56}$ The works linked aluminium with the celebration of Australian science and industrial progress.

\section{MATERIALS INNOVATION: THE CRAFTS AND DESIGN}

Marc Newson's aluminium 'Lockheed Lounge' [1] chair was launched in 1986 at the Roslyn Oxley Gallery in Sydney and received international exposure when Madonna used it in her 1988 'Rain' video and Philippe Starck purchased it for the Paramount Hotel in New York in 1990.57 The sensuous curves and biomorphic forms were also used in designs for the aluminium 'Orgone' chair of 2000. The Lockheed Lounge has become a signature piece for his design firm that has grown through moves to Tokyo (1989), Paris (1992) and London (1997). Newson has become known as a designer who can work on projects of any scale. His company has provided designs for watches, domestic objects and transport and has grown to include one-off collectors' items and prestige designs for corporate clients. ${ }^{58}$ Newson's craft background, in jewellery and silversmithing, has contributed to design knowledge that is able to deal with innovative form in the context of technique and attention to detail. But this has been supplemented by experimentation with CAD software and the opportunity to work with corporate clients who can supply resources and expertise on new materials and technologies. ${ }^{59}$ Newson has become wellknown internationally but he has also become an ambassador for Australian design through his designs for Qantas and though the association that his work is given with other aspects of Australian culture, such as surfing culture. 60

Other Australian craftspeople and designers who have gained international reputations for working with aluminium, include Johannes Kuhnen, Helen Aitken-Kuhnen, Susan Cohn, Ian Ferguson and Gilbert Riedelbauch for jewellery and hollow-ware. ${ }^{61}$ Helen Aitken-Kuhnen and Johannes Kuhnen influenced successive generations of designermakers after setting up a 'Workshop Bilk', at Michelago, $50 \mathrm{~km}$ from Canberra, and teaching at the Canberra School of Art. In 2001 they moved to Queanbeyan, $12 \mathrm{~km}$ from Canberra. Their experimentation with aluminium has been alongside work in other media, such as gold and silver; and for Helen Aitken-Kuhnen, glass and enamel. ${ }^{62}$ Aluminium has therefore had an important place in craft experimentation.

\section{Promotion of Australian DESIGN THROUGH EXHIBITIONS: 2005 - 2007}

Craft historian and critic Grace Cochrane has noted a shift in the alignment of Australian craft experimentation from the fine arts to design. ${ }^{63}$ Historically the cultural relevance of craft for design has been through the transfer of knowledge about materials and technique from hand to machine. ${ }^{64}$ Beyond the production of the work, the connection between material and artefact has become increasingly important for the creation of a designer or maker's identity and is part of the cultural discourse created by those promoting design through exhibitions. The exhibitions 'Vast Terrain' (2005), 'Freestyle' (2006) and 'Smart works' (2007), which all featured work in aluminium by Australian makers, were part of this wider promotional activity.

The 2002 Australian Government's Myer Report discussed the commercial contemporary visual arts and craft sector and its interaction with the wider economy as 
a network, or chain, of individuals, businesses and organisations. ${ }^{65} \mathrm{Craft}$ practitioners were seen to be at the supply end; and at the demand end of the chain were consumers, individuals, businesses and organisations that purchase or view the craft works. The exhibitions, 'Vast Terrain' (2005), 'Freestyle' (2006) and 'Smart works' (2007) acted as intermediaries between production and consumption within this wider context. For 'Vast Terrain', this also included materials producers and manufacturers through working closely with Alcoa World Alumina Australia and The Alcoa Foundation as sponsors of a three year programme. 'Freestyle' and 'Smart works' were primarily supported by craft organisations and museums. Their aims included considering what kinds of conditions were most conducive for the promotion of materials innovation as part of a wider creative, cultural discourse and for economic growth. The exhibitions were a channel of communication through which ideas about innovation were disseminated and celebrated as a way of strengthening the impact of the creative arts.

In 2005 FORM: Contemporary Craft and Design Inc. the not-for-profit organisation representing design and the crafts in Western Australia presented an exhibition 'Vast Terrain - Exploring Uncommon Ground'. ${ }^{66}$ As part of a wider project three designermakers, Robert Foster, Andrew Last and Frank Bauer, were given the opportunity to explore and experiment with aluminium, transferring knowledge from hand to machine.

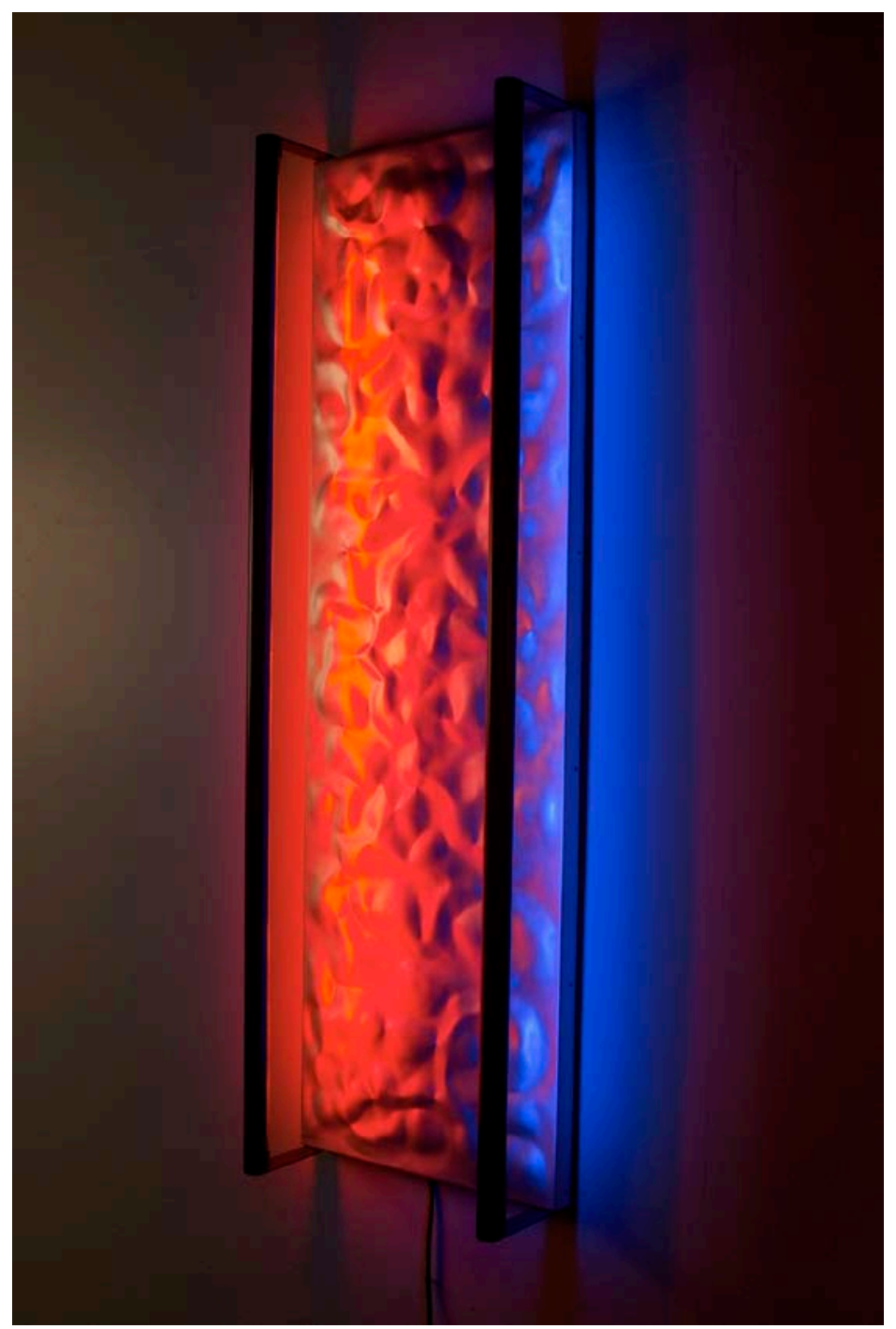

[5] Water-formed anodized aluminium wall-mounted light fitting, designed by Robert Foster. Exhibited as part of 'Vast Terrain - Exploring Uncommon Ground' 2005. Reproduced with permission from FORM. Photograph of works by Czar Photo Design. 
Robert Foster had attended the Canberra School of Art and trained with Johannes Kuhnen. He then set up a commercial studio and production workshop near Canberra and started his production company, F!nk and Co. in 1994, producing work for individual commissions alongside production runs of domestic ware. ${ }^{67}$ Foster has gained an international reputation for his vessel forms, his use of explosives to produce the form of his hollow-ware and an innovative water-forming process for aluminium, which gave the vessels undulating and flowing surfaces. For 'Vast Terrain' he experimented with water-formed anodised aluminium for light fittings. [5] Foster's working methods come from a craft sensibility and have been inspired by the quality of the materials being used. In describing his working methods he has said:

Sometimes I will prototype in the actual material I might finish up making the object with because over time I realise that it is better to actually work with the material that will allow you to finish the object because even if you have to throw it away, or it is not right and you have to start again, at least you have got that piece of material there and you know you can make it in that way with that piece of material if you need to and it is going to work. ${ }^{68}$

In 1988, Andrew Last undertook a Craft Traineeship with the jeweller, Susan Cohn, who was working with aluminium to produce jewellery. He then worked on small-scale intimate jewellery as well as on large-scale commissions. His experimental work with aluminium included the welding of small components to create jewellery pieces and the introduction of miniaturised engineering principles to his work. He developed laser-cut beaten aluminium bowls, for the 'Vast Terrain' exhibition, based on experimentation with processes, including using the CAD software, Xfrog, in conjunction with materials experimentation. He was inspired by aerodynamic forms for previous work but in the 'Vast Terrain' work, which included bowls, lights and jewellery, [6] he was inspired by mathematical formulae. 69

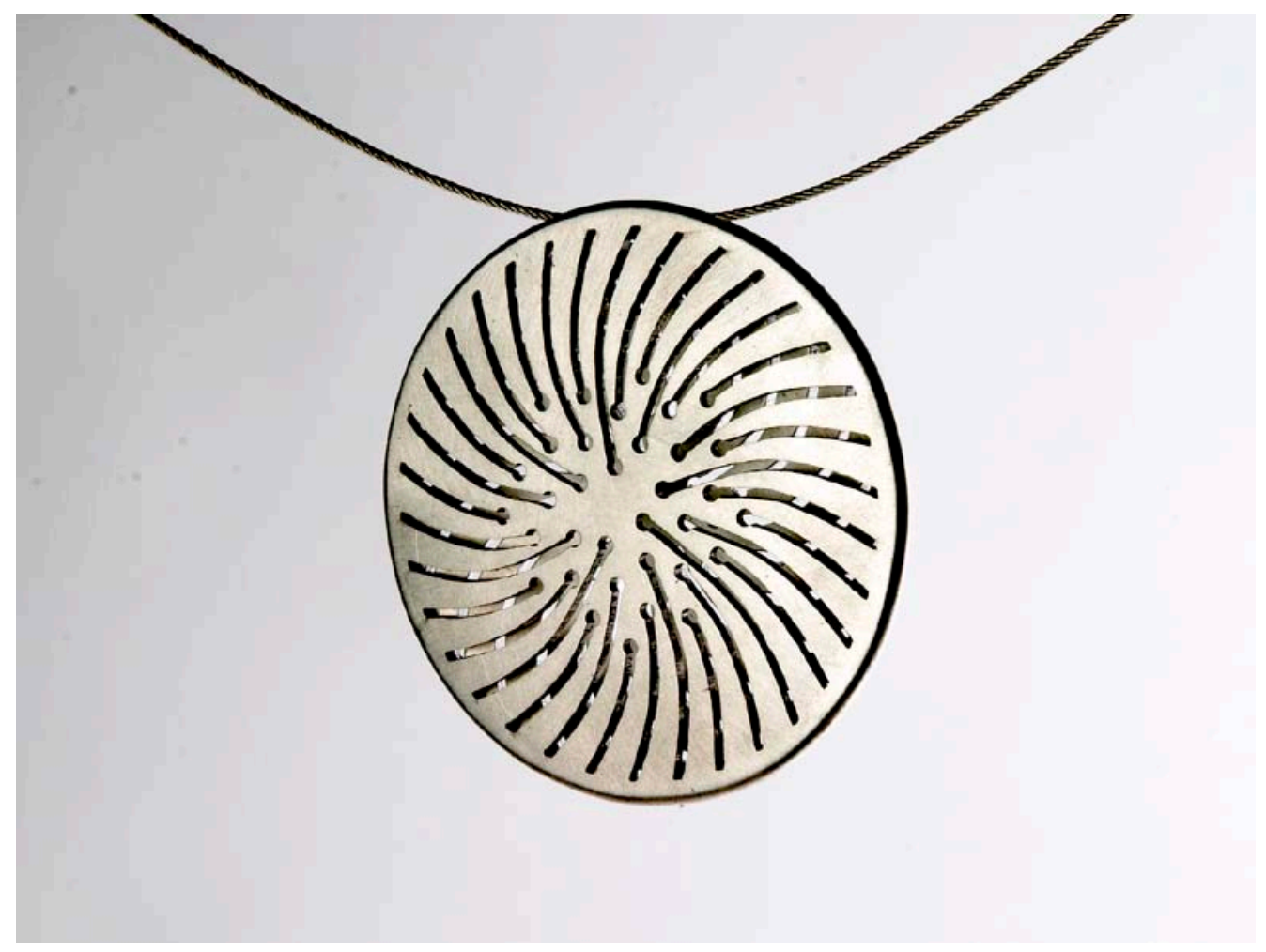

[6] Pendant, designed by Andrew Last. Exhibited as part of 'Vast Terrain - Exploring Uncommon Ground' 2005. Reproduced with permission from FORM. Photograph of works by Czar Photo Design. 
Frank Bauer was trained in Germany and has also worked in London, Sydney and Adelaide on direct commissions for galleries and exhibitions. 'Vast Terrain' included examples of his designs for wall lights [7] that expressed an interest in movement and interaction. The works used a patented system for small low-voltage lamps as visual connectors through a structure of perforated anodised aluminium sheets. ${ }^{70} \mathrm{His}$ inspiration has been varied, including the energy found in Aboriginal art and textile processes and construction. Minimalist sculpture has been another inspiration, but he has kept a strong focus on function and purpose for his work. ${ }^{71}$

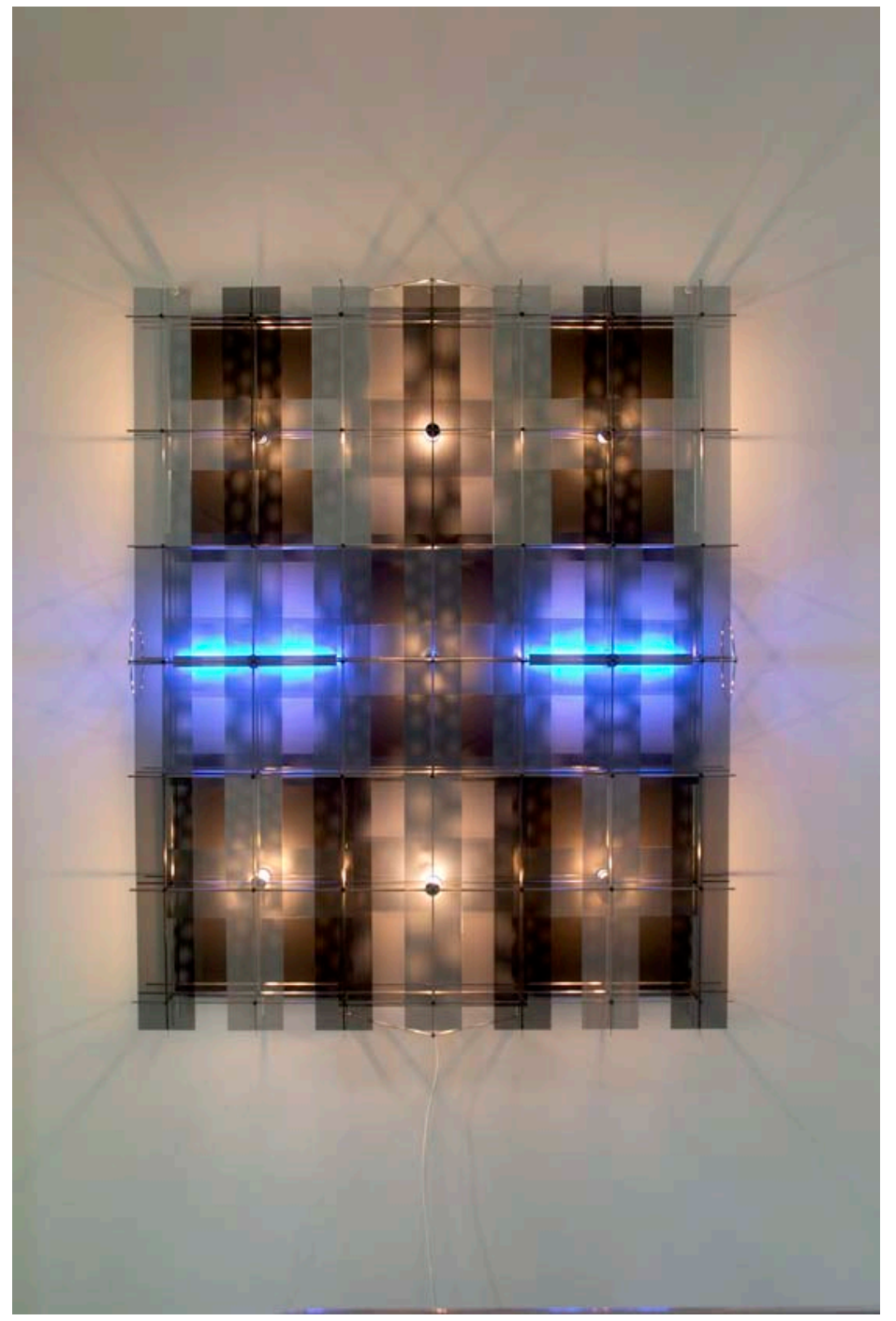

[7] Wall light designed by Frank Bauer. Exhibited as part of 'Vast Terrain - Exploring Uncommon Ground' 2005. Reproduced with permission from FORM. Photograph of works by Czar Photo Design.

One aim of the FORM 'Vast Terrain' exhibition was to enhance a regional and national cultural identity and to give the designers the potential to design prototypes destined for an export market. At the same time, the outcomes were part of a wider concern for the development of the creative industries and creative clusters. FORM was building an artistic programme that enhanced and commercialised the creativity of designers and craftspeople, but the programme was also targeted at the business and industrial sector. Not only was support for the development of the creative work desirable but the idea was also to offer the corporate sector new sources of inspiration and innovation in creative thinking. Additionally, because of the association of the crafts with the arts, they were using the creative works as conveyors of symbolic and emotional values. The aim was to connect the finished aluminium product back to the source of the material in 
Western Australia through association with a sense of place; with Western Australia being a source of both raw materials and creative talent to make those raw materials into desirable products.

As already mentioned, the potential of the designer as an 'end user' to use aluminium and other light metals imaginatively was noted in the Australian Federal Government's, Light Metals Action Agenda's (LMAA) recommendations. The report suggested identifying and targeting specific end users (e.g. architects/designers), developing strategies to engage them, including through their industry associations, educational/training institutions and/or the use of design or other awards. ${ }^{72}$ Foster, Last and Bauer were following individual paths of experiment and exploration but their work also created the content for a wider discussion of the use of aluminium in design.

The other two exhibitions, 'Freestyle' and 'Smart works' held in 2006 and 2007, included makers who experimented with aluminium. These exhibitions made reference in curatorial narratives to globalisation and national identity, but they did not make associations with a sense of place and a specific locality, that were evident in the 'Vast Terrain' exhibition.

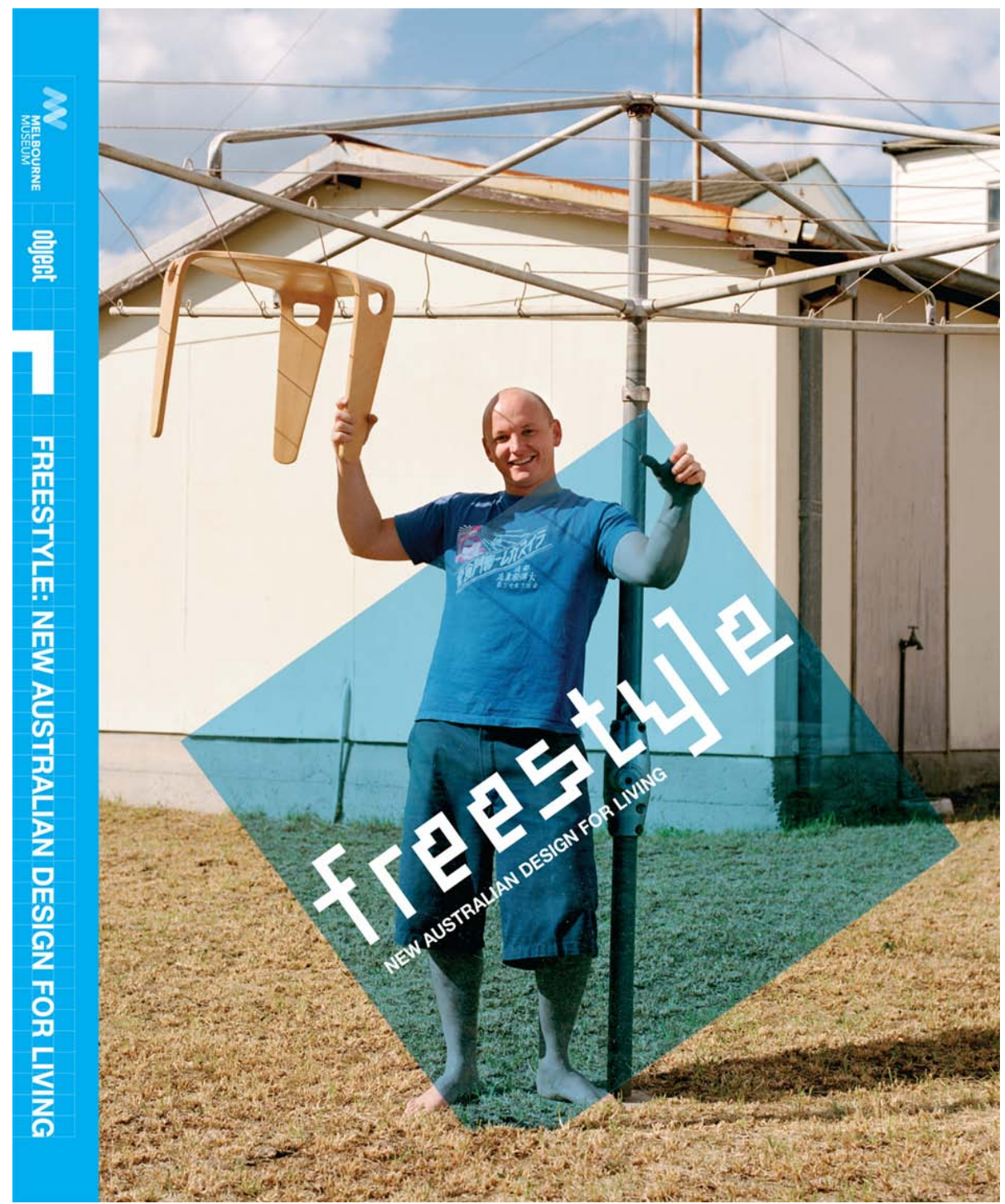

[8] Cover of 'Freestyle' catalogue. Published with permission from Object, from Brian Parkes (ed.), 2006, Freestyle: New Australian Design for Living, Sydney: Object: Australian Centre for Craft and Design \& Melbourne: Melbourne Museum. Cover art designed by Frost Design, Sydney. 
The 2006 exhibition 'Freestyle: new Australian design for living' was a collaboration between Object: Australian Centre for Craft and Design and Museum Victoria. ${ }^{73}$ It was a showcase for Australian design and aimed to explore the Australian identity, noting: 'The work reflects the tenacity, inventiveness and dedication to quality that are emerging hallmarks of the most outstanding Australian design'. ${ }^{74}$ Five factors, cultural diversity, geographic diversity, small population and limited market, proximity to Asia and diminishing manufacturing base, were the factors shaping the context for these makers. The exhibition included work in aluminium by Foster and F!ink and also Bernabei and Freeman, Lucas Chirnside, and Bianca Looney, Susan Cohn and Oliver Smith. The 'Freestyle' catalogue projected the designers as 'personalities' through carefully posed photographic portraits. All the designer-makers were shown in exterior locations with their designs as 'props.' The cover associated the identity of the individual designer-maker with an Australian national identity by having designer Jon Goulder pose with an Australian design icon - a Hills Hoist rotary clothesline in a suburban backyard. [8]

The 'Smart works' exhibition at the Powerhouse, Sydney in 2007, showed the work of 40 Australian and New Zealand designers and featured aluminium work by Foster and Last and others for domestic products, furniture and sculpture. ${ }^{75}$ Other designers using aluminium in their work included Donna Marcus, Rohan Nichol, Oliver Smith, Jon Goulder and Jill Kinnear. For the designer-makers represented, this exhibition celebrated their understanding of materials and technologies, their skills and 'lifelong commitments to a materials-based practice'. ${ }^{76}$ It was also part of the Australia Council's international craft strategy and the Council's work to connect the arts and craft with business in a global context. The makers were therefore placed within the context of the creative industries as a global phenomenon, crossing the boundaries of traditional crafts and smart new technologies and specialist industries. The three exhibitions therefore concentrate on differing themes; these were sense of place, design for living and globalisation.

\section{SUSTAINABLE PRODUCTION AND CONSUMPTION}

Aluminium is a useful material with high scrap value and infinite recyclability. Recycling aluminium makes a significant contribution to sustaining energy resources; through using recycled aluminium there is a saving in power used for manufacturing the material. For most aluminium products, aluminium is not completely consumed but rather used. Therefore, a life cycle of an aluminium product is not 'cradle-to grave', but rather 'cradle-to-cradle'. ${ }^{77}$ This means that the lifecycle of an aluminium product usually ends when the recycled aluminium is rendered in a form usable for a new aluminium product; for example, as an ingot. ${ }^{78}$ The International Aluminium Institute started to collect information for lifecycle assessment from 1998. This supported their understanding of sustainable development as 'a tool for satisfying stakeholder concerns and measuring business performance.' 79 Their investigations of the production of aluminium drew on the Australian experience, but they relied on the European Aluminium Association for information on recycling and consumer activities. These studies have most often considered packaging, although there is a growing body of information on products, especially cars. ${ }^{80}$

The Centre for Design at RMIT University in Melbourne has raised the profile of sustainable design for design education and practice in Australia. TheCentre hosted an international conference on ecodesign in 1991, have produced reports and worked with industry to produce new design methods, tools and products, through the EcoReDesign programme in 1997 and 1999. 81 Their work in cooperation with other organisations in 
Melbourne led to a detailed study of lifecycle assessment and recycling, which included the consideration of aluminium alongside other materials such as glass and paper. This approach to considering materials was strongly interdisciplinary and included the input of product designers, social scientists, and engineers within a network that included industry and government. In Linking Innovation, Design and Sustainability: Learning from Real World EcoDesign Projects, John Gersakis noted, in 2001, that there was an emphasis on eco-efficiency and cleaner production as important tools being used by industry, government and the community. These analytical tools were providing six-star energy rated appliances, 'AAA' water conservation-rated shower heads and recycled content packaging. As a centre, however, they were working towards fostering more input from the demand side and from design. Gersakis also mentioned product stewardship where manufacturers were offering services instead of products. He expected this to shift the focus from the value of products to the value of their utilisation. 82

Domestic recycling in Australian increased in the 1980s and 1990s after the introduction of kerbside recycling schemes. Government involvement was through the Australian and New Zealand Environment Conservation Council (ANZECC), which operated between 1991 and 2001 to develop policies on environmental and conservation issues. ${ }^{83}$ In 1999 ANZECC set up the National Packaging Covenant as a National Environment Protection Measure (NEPM). In 2001, these recycling initiatives were transferred to the Environment Protection and Heritage Council (EPHC). ${ }^{84}$ By 2002, 63\% of aluminium cans were recycled in Australia. ${ }^{85}$ [9]

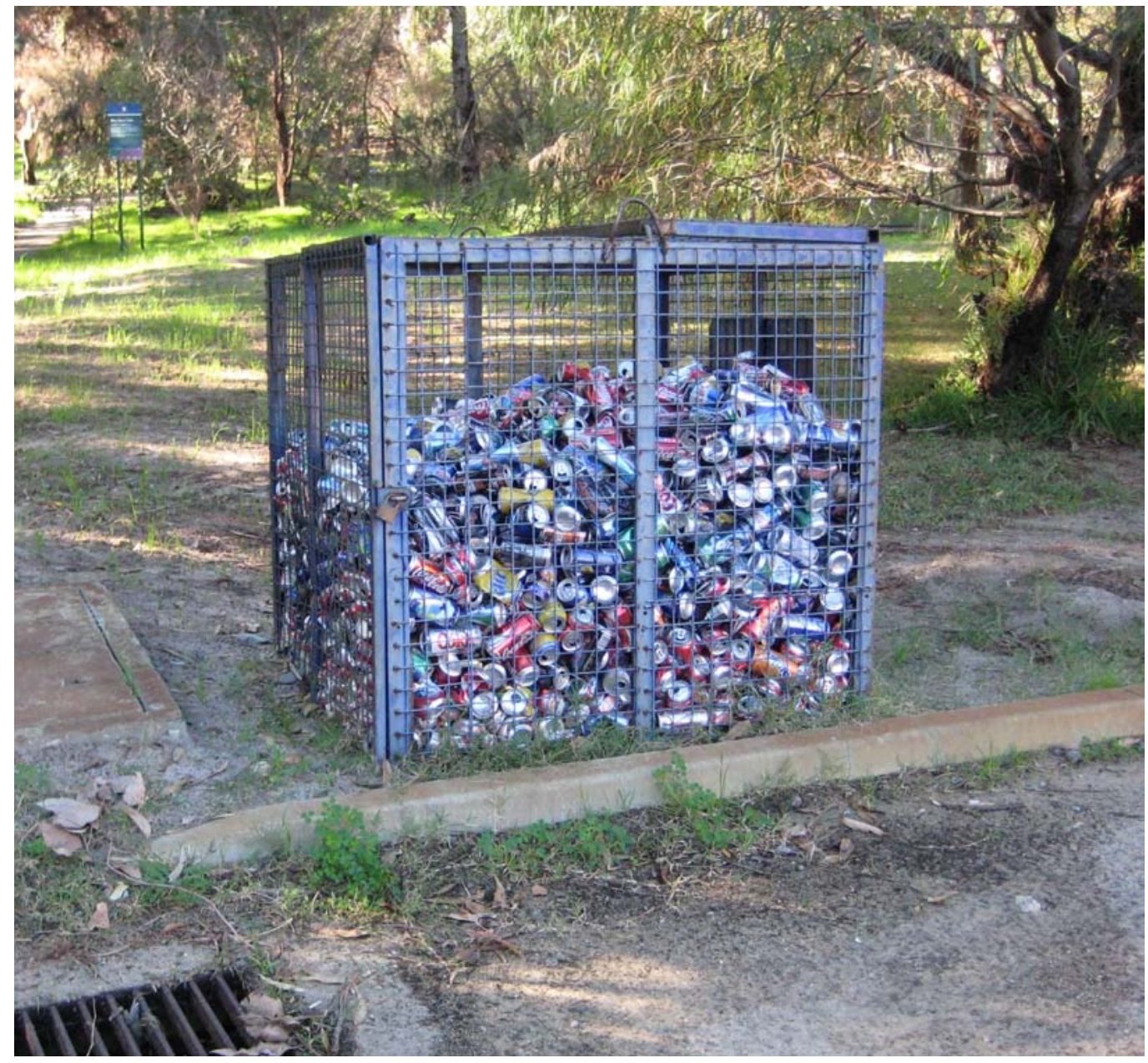

[9] Aluminium can recycling collection, Perth, Western Australia, 2007. Reproduced with permission from author. 
Attitudes to aluminium were also affected by the extent to which recycling was integrated into everyday living. South Australia is the only Australian state to offer a refund on recyclable bottles and containers. This refund, offered at the retail point, follows on from a returns tradition dating back to the 19th century when the Adelaide Bottle Company collected beer bottles, and soft drinks containers were returned to shops. The Beverage Container Act legislation in 1975 reinforced the system of payment for returns, which became part of an Environmental Protection Act of 1993.86

\section{CONCLUSION}

For the story of materials in the modern era, Doordan has mentioned that 'discussions of what must always be coupled with an appreciation of when in order to capture the fine details as well as the big picture'. ${ }^{87}$ This article has also included a discussion of 'where'. Through a study of aluminium, in the context of production, promotion and consumption, this article has positioned some unique aspects of Australian production and design within the global economy. I will now look at the issue of national identity in more detail. This has been a popular theme in interpretations of Australian design. Design exhibitions, in particular, have been key contributors to this discourse. Aluminium products have featured in exhibitions promoting Australian design, exhibited both alongside more traditional materials, as in 'Freestyle' and 'Smart works', and as a central focus, as in 'Vast Terrain'. These exhibitions showed a range of overlapping approaches to local and global circumstances.

In the range of areas discussed across manufacture, production and consumption there were manufacturing interests that were predominantly global, as in the production of the raw materials. Also, the resources industries, run by international companies exporting the material had always been part of global manufacture. There were examples of design production that was locally and globally defined and also locally situated contributions to sustainable production. There were no obvious causal links between areas; but in some specific contexts organisations were working to make links, either between areas of production along the supply chain or between aluminium and other areas of cultural meaning.

By 2001 the Australian Government's Light Metals Action Agenda (LMAA) was calling for greater synergies between production and consumption. For the aluminium industry, an important part of the Australian resource economy, there was a call for recognition of the importance of designers for providing 'added-value' and the need for a greater uptake of aluminium by end-users. The example of innovative ship design, such as Austal's trimaran fast ferry the 'Benchijigua Express' was a success story in this context.

The use of aluminium by designers with a craft or arts education was featured by curators organising exhibitions to promote Australian design in the 1990s. These exhibitions created varying degrees of connection between aluminium the material, and symbolic association with place or national identity. The three exhibitions discussed earlier used different themes to engage with local and global conditions; 'Vast Terrain' used the local to refer to sense of place, 'Freestyle' used the idea of design for living and 'Smart works' called for a considered response to globalisation. These exhibitions were engaging with a discourse on design which had become more outward looking from the 1980s.

Through comparisons over time it is possible to see the different opportunities available for Australian designers in national and international design markets. The use of aluminium in furniture by Gordon Andrews and Marc Newson show the changes in 
context and approach within design from the 1950s 'modern' to the 1980s 'postmodernism' but more importantly, their work exemplifies an approach to design that is more international than usually recognised in the work of Australian designers. ${ }^{88}$ In comparing the work of these two designers it can be seen that in the 1950s Andrews was bringing European experiences back to Australia. In the 1980s, Newson's work has confidently gone the other way: from Australia to the international design market. With Australian design activities becoming more outward-looking there were more confident definitions of the local within global networks. This shift was evident from the 1970s. For Australians the world was no longer in the background. With the world in the foreground, the nation state became a part of the larger whole. ${ }^{89}$

The emergence of a greater emphasis on consumption, in addition to production, is evident in the subject matter of design promotion. The Comalco commissions of the 1970s were examples of artists being given the opportunity to create artworks for public commissions, or where their work was used to celebrate the advances of science within settings, such as a hydro-electric scheme. There were links between the manufacturers (as patrons) and the artists, where sponsorship of the arts provided the company with an opportunity to foster social responsibility and to link progress through scientific innovation and the harnessing of natural resources to works for the public good within Australia. The 'Vast Terrain' exhibition had similar aims when it linked the interests of Alcoa World Alumina Australia and The Alcoa Foundation to the creative industries, to reflect a 'relationship between cultural capital and the advance of industry' linking creativity to the expansiveness of the Australian landscape, a sense of exploration and a 'journey into new territory'. ${ }^{90}$ Innovation was celebrated as a feature common to both the resource sector and experimental design within a globally defined context of the creative industries. The exhibition was working within the rhetoric of Australia becoming a creative nation; with culture in the simultaneous role of 'leader, catalyst and cement with the capacity to enhance economic and social wealth'. ${ }^{91}$

As well as documenting work from designers contributing to the creative industries, 'Smart works' celebrated diversity and placed a strong emphasis on the artefacts as a means of representing the technical and business skills of the designers and their value in the export market. In 'Freestyle' the individual designer's work was shown as part of an urban culture of consumption. This also made reference to suburban culture and lifestyles often celebrated as part of an Australian national identity. As noted earlier, Jackson has argued that associations of pioneering innovation, roughness and 'no fuss design', with design with Australian national identity, have given Australians 'a view of themselves in relation to design which the facts simply do not support'. ${ }^{92}$ His study was dependent on sources up to the early 1990s. The depiction, in 2006, of the Hills Hoist, a typical Australian design icon, on the cover of the 'Freestyle' exhibition catalogue perpetuated these ideas, but is especially a reference to the suburban design landscape. The catalogue contains images of the designers in predominantly urban contexts, which separated them as designers from industry and manufacture and suggested that they were integral to a celebrated ordinary Australian 'way of life' - as part of consumer culture rather than of a manufacturing culture.

More generally, in the late 20th century, Australian national identity was no longer portrayed through commodities produced as a part of the British Empire but showed a mix of unique flora and fauna, heritage sites as tourist destinations, urban culture and indigenous history. Indigenous work was appropriated or celebrated in graphic or fashion areas of design, especially in relationship to tourism. ${ }^{93}$

Aluminium has been used in narratives of science and the future, a 'way of life', but has had little association with an Indigenous history that has become an integral part of viewing the Outback in the Australian tourism media. Yet mining activities are part of 
the reality of the Outback. This contrasts with the celebration of other materials, such as wool, that were an integral part of the colonial history of Australian manufacturing and its export economy. The 'Vast Terrain' exhibition played with the metaphor of a vast expansive landscape but it is an unpopulated landscape of ancient landforms. It was a parallel theme to the celebration of the material within the work of the sophisticated designer. This reflects the way the Bush and Outback is perceived whereby, as noted by Richard Waterhouse, there is an increasingly diverse regional Australia, where tourism, agriculture and mining are all important but their interests are not identical and they do not have a shared sense of identity and purpose. ${ }^{94}$ Reference to the qualities of pioneering Australia did not fit so well with the presentation of aluminium in a global context.

For a consideration of materials history, two questions were raised. Can histories of materials show networks and relationships between resources, the technical, objects, social activities and cultural meaning? Does this provide new areas of research for design history? For Australian design at the end of the 20th century, this discussion of aluminium suggests that materials histories are relevant for showing areas of greatest activity rather than connections of activity across production and consumption.

The contrast between preciousness and ubiquity, noted in existing histories of aluminium, was also borne out in Australian examples. Aluminium has continued to be both accepted and celebrated. In order to uncover connections and areas of greatest activity it has been useful to be inclusive in choosing which areas to study and consider aluminium across a range of areas from materials production to consumption. This takes into account Latour's suggestion to flatten the landscape and disassemble the natural (here a resource) and the social. From the 1980s, there was a celebration of the potential of aluminium as a 'craft' material, where its malleability and potential for a range of unpolished, polished or anodised finishes provided scope for a potentially rich formal and structural language for designers. In this context, as suggested by Science and Technology Studies, we should not forget the power of human agency and the catalyst of materials for inspiration and application. In this respect, a close examination of the ways in which designers used aluminium imaginatively and then how these examples were used within the promotion of design to promote a sense of Australian identity is important.

Besides adding to existing accounts of aluminium, this study of a material has been useful for rethinking familiar themes such as national identity. This has demonstrated close links between the local and the global. It is therefore a contribution to a 'world' history of design as it reconfigures locations considered to be at the margins of design activity and influence.

\footnotetext{
${ }^{1}$ For surveys of Australian design and craft see: M. Bogle, Design in Australia 1880-1970, Craftsman House, 1997. G. Cochrane, The Crafts Movement in Australia: A History, NSW University Press, 1992. For a discussion about methods of interpreting Australian design see: T. Fry, 'A Geography of Power: Design History and Marginality', in V. Margolin, \& R. Buchanan (eds.), The Idea of Design: A Design Issues Reader, MIT Press, 1995, pp. 204-218. S. Jackson, 'The "StumpJumpers:" National Identity and the Mythology of Australian Industrial Design in the Period 1930-1975', Design Issues, vol. 18, no. 4, 2002, pp. 14-23. S. Jackson, 'Sacred Objects - Australian
} 
Design and National Celebrations', Journal of Design History, vol. 19, no. 3, 2006, pp. 249-255. D. Whitehouse, 'The Panoramic Narrative and the Production of Historical Consciousness: This is Australia', in J. Redmond, D. Durling, A. De Bono (eds.) Futureground: Design Research Society International Conference 2004, Proceedings, 2004, CD-Rom.

2 Bogle, (1997) op. cit. M. Bogle, Designing Australia: Readings in the History of Design, Pluto Press, 2002.

${ }^{3}$ Bogle, (1997) op. cit. M. Maynard, 'Grassroots Style: Re-Evaluating Australian Fashion and Aboriginal Art in the 1970s and 1980s', Journal of Design History, vol. 13, no. 2, 2000, pp. 137 150.

${ }^{4}$ Jackson, (2002) op. cit., Jackson (2006) op cit., Whitehouse, (2004) op cit.

${ }^{5}$ Fry, op. cit. In this discussion Fry notes the particular take up of modernism in Australia and the way that bricolage explains the take up of post-modernism.

${ }^{6}$ Ibid., p. 213.

${ }^{7}$ L. Veracini, 'Historylessness: Australia as a Settler Colonial Collective', Postcolonial Studies vol. 10 , no. 3,2007 , p. 271-285.

8 Jackson, (2006) op. cit., p. 255.

${ }^{9}$ See G. Blainey, The Rush That Never Ended: A History of Australian Mining, 4th ed., Melbourne University Press, 1993. T. Griffiths and L. Robin, (eds.), Ecology and Empire: Environmental History of Settler Societies, Melbourne University Press, 1997. R. Grove, Green Imperialism: Colonial Expansion, Tropical Island Edens, and the Orgins of Environmentalism, Cambridge University Press, 1995. L. J. Proudfoot and M. M. Roche, (eds.), (Dis)Placing Empire: Renegotiating British Colonial Geographies, Ashgate, 2005. T. Richards, The Imperial Archive: Knowledge and the Fantasy of Empire, Verso, 1993.

${ }^{10}$ A. A. Moles, 'Design and Immateriality: What of It in a Post Industrial Society?', in Margolin \& Buchanan, (eds.), op. cit. pp. 268-274. There are other concepts that have become integral to these debates and have been successfully used to explain digital culture. This includes the concept of dematerialisation as a way of understanding materiality; workability of a material as a definition of its possibilities as a medium. M. McCollough, Abstracting Craft: the Practiced Digital Hand, MIT Press, 1996; concepts of disassembly and recycling P, Dormer, Design Since 1945, Thames \& Hudson, 1993; concepts of transience L. Sandino, 'Here Today, Gone Tomorrow: Transient Materiality in Contemporary Cultural Artefacts', Journal of Design History, vol.17, no. 3, 2004, pp. 283-294.

${ }^{11}$ S. M. Pearce, Museum Objects and Collections a Cultural Study, Leicester UP, 1992, p. 98.

12 M. Baker, 'Some Object Histories and the Materiality of the Sculptural Object', in S. Melville (ed.) The Lure of the Object, Sterling and Francine Clark Art Institute, 2005, p. 130.

${ }^{13}$ V. Buchli, The Material Culture Reader, Berg, 2002, p. 2-22.

14 T. Dant, Material Culture in the Social World: Values, Activities, Lifestyles, Open University Press, 1999 , p. 2.

15 J. Attfield, Wild Things: The Material Culture of Everyday Life, Berg, 2000. Dant, ibid. 
16 W. D. Kingery, 'Materials Science and Material Culture,' in W. D. Kingery (ed.) Learning from Things: Method and Theory of Material Culture Studies, Smithsonian Institution Press, 1996, p. 176.

17 D. Doordan, 'On Materials', Design Issues, vol.19, no. 4, Autumn, 2003, pp. 7-8. This differentiation is adopted from R. Buchanan 'Wicked problems in Design Thinking', Design Issues, vol.8, no. 2, Spring, 1992, p. 10.

18 Ibid., p. 4.

${ }^{19}$ L. Marx, 'Technology: The Emergence of a Hazardous Concept', Social Research, vol. 64, no. 3 1997, pp. 965-988.

20 P. Verbeek, What Things Do: Philosophical Reflections on Technology, Agency, and Design, Pennsylvania State University Press, 2005, p. 100.

${ }^{21}$ D. E. Nye, Technology Matters: Questions to Live With, MIT Press, 2006, .

22 B. Latour, Reassembling the Social: An Introduction to Actor-Network-Theory, Oxford University Press, 2005.

23 Ibid. p. 85.

24 Ibid. p. 109.

25 Ibid. p. 114.

${ }^{26}$ Ibid. p. 109.

27 W. Orlikowski, 'Material Knowing: The Scaffolding of Human Knowledgeability', European Journal of Information Systems, vol. 15, no. 5, 2006, p. 185.

28 P. Carter, Material Thinking: The Theory and Practice of Creative Research, Melbourne University Publishing, 2004, p. 7.

${ }^{29}$ Reclaiming 'secondary' materials, such as scrap steel, rags and used paper, referred to as recycling was first recorded as such by the OED in 1926. See: P. Desrochers, 'How Did the Invisible Hand Handle Industrial Waste? By-Product Development before the Modern Environmental Era', Enterprise \& Society, vol. 8, no. 2, 2007, pp. 348-374.

30 European Aluminium Association, Aluminium the Metal, 2003.

http://www.eaa.net/eaa/index.jsp [accessed 29 December 2006].

31 S. Nichols, Aluminum by Design, Harry H. Adams, 2000.

32 E. Schatzberg, 'Symbolic Culture and Technological Change: The Cultural History of Aluminum as an Industrial Material', Enterprise \& Society vol. 4, no. 2, 2003, p. 227. He states 'Technological innovation always involves creating new meanings along with new artefacts and material practices. Failure on the symbolic level can be just as devastating to the success of an innovation as failure on the material plane.' p. 230.

33 Ibid., p. 243.

34 Ibid., p. 263. 
35 C. Edwards, 'Aluminium Furniture, 1886-1986', Journal of Design History, vol. 14, no. 3, 2001, p. 224.

${ }^{36}$ For an overview of domestic artefacts see: P. Sparke, 'Cookware to Cocktail Shakers: the Domestication of Aluminum in the United States, 1900-1939', pp. 112-139 and C. Vogel, 'Aluminum: a Competitive Material of Choice in the Design of New Products, 1950 to the Present', p. 140-165 in Nichols, op. cit.

37 Schatzberg, op. cit., pp. 258-263.

38 Design Museum, Jonathan Ive on Apple, 2004.

http://www.designmuseum.org/design/jonathan-ive [accessed 5 November 2004].

${ }^{39}$ Nichols, op. cit., pp. 268-271 and pp. 274-5.

40 Australian Aluminium Council (AAC), Australian Aluminium Statistics, 2007. http://www.aluminium.org.au/Page.php?s=1030 [accessed 14 June 2007].

${ }^{41}$ Australian Aluminium Council (AAC), Aluminium and the Australian Economy: A Report to the Australian Aluminium Council, 2000, pp. 5-6 and p. 11.

42 Ibid., p. 13.

43 Ibid., p. 14-15.

44 Ibid., p. 20.

${ }^{45}$ International companies with Australian interests include Alcan, Alcoa, Kaiser, Pechiney, Reynolds and Alusuisse. Australian Aluminium Council (AAC), The Australian Aluminium Industry, 2001, p. 1.

${ }^{46}$ Strategic Leaders Group (SLG) LMAA, Australia Leading the Light Metals Age Strategic Leaders Group Report to Government, 2001, p. 7.

http://www.industry.gov.au/assets/documents/itrinternet/lmaa.pdf [accessed 30 Jan 2004].

47 Ibid., p. 42.

${ }^{48}$ Edwards, op. cit., p. 208.

${ }^{49}$ P. Pae, 'A Plane as Big as the Globe', LA Times, 17 January 2005.

${ }^{50}$ Austal, Tri This for Size, 2004. http://www.austal.com/index.cfm?objectid=4487AB0B-A0CC3C8C-D94677DFE8B7F85E [accessed 16 June 2007]. Austal, Benchijigua Express, 2007. http://www.austal.com/index.cfm?objectID=6955E09C-A0CC-3C8C-D9FD2E4C71CE8F0E [accessed 16 June 2007]. C. Bolt, 'Trimaran Launched to Interest Worldwide', The West Australian, 4 September 2004.

${ }^{51}$ Lloyd's Register, Lloyd's Register Sets the Rules for Aussie Rules, Lloyd's Register, 2003. http://www.lr.org/News+and+Events/News+Archive/2003/Lloyds+Register+sets+the+rules+fo r+Aussie+Rules.htm [accessed 28 June 2007].

52 LMAA, op. cit., p. 22.

${ }^{53}$ G. Andrews, Gordon Andrew: A Designers Life, New South Wales University Press, 1993, p. 98. 
54 Ibid., p. 88.

55 Ibid., p. 94.

${ }^{56}$ R. Robertson-Swann, 'Architecture and Sculpture: The Comalco Invitation Award', Aluminium, no. 4, 1971, pp.6-11.

${ }^{57}$ H. Meijer, 'Flashback,' Frame, no. 16, 2000, p. 33. Nichols, op. cit., pp. 264-5.

${ }^{58}$ R. Jana, 'Marc Newson and the Art of Design,' BusinessWeek, 15 December 2006.

59 C. Lloyd Morgan, Marc Newson, Thames \& Hudson, 2003; Design Museum, Marc Newson, 2004. http://www.designmuseum.org/design/index.php?id=11 [accessed 12 November 2004]. Marc Newson, Marc Newson, 2004. http://www.marc-newson.com/ [accessed 11 October 2004].

60 Australian Government, Culture and Recreation Portal: Australian Design, 2007. http://culture.gov.au/articles/design/index.htm [accessed 16 June 2007].

61 M. Hinchcliffe, '31@20: Gold and Silversmithing', Crafts Arts International, no. 53, 2001, pp.8586; M. Hinchcliffe, 'Multiple Idioms in Metal \& Glass', Crafts Arts International, no. 54, 2002, pp. 34-39.

${ }^{62}$ Hinchcliffe, (2001), (2002), op. cit. According to Hinchcliffe aluminium was 'a signature material of the workshop.'

63 G. Cochrane, 'Shapes of Things to Come: Australia', Crafts, no. 181, 2003, p.14.

${ }^{64}$ Cochrane, op. cit.; C. Frayling, (ed.), Beyond the Dovetail: Craft, Skill and Imagination, Crafts Council, 1991; T. Harrod, The Crafts in Britain in the Twentieth Century, Yale University Press, 1999.

${ }^{65}$ R. Myer, Report of the Contemporary Visual Arts and Crafts Inquiry (Commonwealth Department of Communications, Information Technology and the Arts), 2002.

http://www.dcita.gov.au/Article/0,0_1-2_2-4_111225,00.html [accessed 4 November 2003].

66 The exhibition ran in Perth, 4 February to 12 March 2005; Sydney Opera House Exhibition Hall, 26 March to 15 May 2005; and Melbourne Museum 29 July 2005 to 6 November 2005. Vast

Terrain was sponsored by the Australia Council, Alcoa World Alumina Australia and The Alcoa Foundation, and supported by Object's National Exhibitions Strategy funded by the Australia Council. Form had already run a project that expanded the parameters of design for the West Australian timber industry. This was in response to the need for professional development of Western Australia's fine wood sector in the wake of the cessation of old-growth timber logging in 2001. This work was disseminated through a conference in August 2002 and a publication, Shifting Foundations. See: Craftwest, Shifting Foundations: The Collection of Papers of the Designing Futures Forum, Craftwest, 2003.

${ }^{67}$ Fink \& Co, 2004. http://www.finkdesign.com/index.htm [accessed 15 May 2004].

68 Interview session with Robert Foster, Queanbeyan, ACT. 24 June 2004.

${ }^{69}$ Australian Silver Exhibition Catalogue - Andrew Last, RMIT, 2000.

http://www.rmit.edu.au/browse?SMID=e2whbtccezw [accessed 31 January 2004]. 
A. Nicholls, Vast Terrain: Exploring Uncommon Ground, FORM Contemporary Craft and Design, 2005, p. 37.

${ }^{70}$ Frank Bauer was born in Hannover, Germany in 1942 and arrived in Australia in 1971. His work was influenced by early modernism arising from his craft and design training in Germany. His work is documented in exhibition catalogues including: Frank Bauer: Designer -Jewellery, Metalwork, Lighting, 1975-2000, Frank Bauer, 2000. See also: Frank Bauer,

http://www.nga.gov.au/Material/SDetail/bauer.htm [accessed 13 January 2004]. Frank Bauer, 2004, http://www.phm.gov.au/exhibitis/archive/bauer/ [accessed 13 January 2004]. Nicholls, op. cit., pp. 18-25.

${ }^{71}$ Nicholls, op. cit., p. 22.

72 LMAA, Light Metals Action Agenda Working Paper No 4 Downstream Manufacturing (August 2001), 2001.

http://www.industry.gov.au/assets/documents/itrinternet/ImDownstream110901.pdf. p. 42. [Accessed 30 Jan 2004].

${ }^{73}$ B. Parkes, Freestyle: New Australian Design for Living, Object: Australian Centre for Craft and Design \& Melbourne Museum, 2006.

${ }^{74}$ Ibid., p. 15.

${ }^{75}$ G. Cochrane, Smart works: Design and the Handmade, Powerhouse Publishing, 2007.

${ }^{76}$ Ibid., p. 8.

77 International Aluminium Institute, Life Cycle Assessment of Aluminium: Inventory Data for the Worldwide Primary Aluminium Industry (Year 2000 Aluminium LCI Report for the International Aluminium Institute), 2003, p. 45.

${ }^{78}$ Ibid., p. 45.

For an aluminium ingot the embodied energy saving per kilogram in the production of recycled product as compared to an equivalent virgin product is estimated at $93 \%$ where the product is taken to the production of aluminium ingots. T. Grant et al, Stage 2 Report for Life Cycle

Assessment for Paper and Packaging Waste Management Scenarios in Victoria, ECORecycle Victoria, 2001. p. xi.

For an indication of changes in production on a global scale, especially for America, see K. Das Subodh et al, 'Energy Implications of the Changing World of Aluminum Metal Supply', JOM, vol.56 2004, pp. 14-17.

${ }^{79}$ International Aluminium Institute, op. cit., 2003, p. 3.

80 International Aluminium Institute, The Aluminium Industry's Sustainable Development Report, 2002. G. Johansson, T. Magnusson, 'Eco-Innovations - a Novel Phenomenon?' The Journal of Sustainable Design, no. 7, 1998, p. 17. See also: A. Gesing, 'Assuring the Continued Recycling of Light Metals in End-of-Life Vehicles: A Global Perspective', JOM, vol. 56, no. 8, 2004, pp. 18-27.

81 J. Gertsakis, H. Lewis, and C. Ryan, A Guide to EcoReDesign, National Centre for Design at RMIT, 1997. T. Grant, 'Australasia's Focus for Sustainable Design and LCA', Clean Products and Processes vol.2, no. 4, 2001, pp. 195-196. Grant et al. (2001) op.cit,. C. J. Ryan, M. Hosken, and D. Greene, 
'Ecodesign: Design and the Response to the Greening of the International Market', Design Studies vol. 13, no. 1, 1992, pp. 3-22.

82 J. Gertsakis, ed., Linking Innovation, Design and Sustainability: Learning from Real World Ecodesign Projects, National Centre for Design at RMIT, 2001, pp. 17-18.

${ }^{83}$ Australian Government Department of the Environment and Water Resources, Australian and New Zealand Environment Conservation Council (ANZECC), 2007.

http://www.environment.gov.au/about/councils/anzecc/index.html\#what [accessed 24 June 2007].

${ }^{84}$ EPHC was created by amalgamating the National Environment Protection Council (NEPC), the environment protection components of the Australian and New Zealand Environment and Conservation Council (ANZECC), and Heritage Ministers' Meetings. The natural resource management components of ANZECC were transferred to the Natural Resource Management Ministerial Council. In October 2003, EPHC was renamed the Environment Protection and Heritage Council of Australia and New Zealand, but continues to be known as the Environment Protection and Heritage Council. See: Environment Protection and Heritage Council (EPHC), Welcome to the Environment Protection and Heritage Council (EPCH), 2007.

http://www.ephc.gov.au/index.html [accessed 24 June 2007].

85 T. Ha and J. Dee, The Recycling Olympics: An International Waste and Recycling Comparison of Australia and 10 Other Developed Nations, Planet Ark, 2004, p. 8. In this report Australia was a 'mid-performing nation.'

${ }^{86}$ National Trust of South Australia, 2006, BankSA Heritage Icons, 2006.

http://www.nationaltrustsa.org.au/heritage_icons_2006.htm [accessed 17 June 2007].

${ }^{87}$ Doordan, op. cit., p. 7.

${ }^{88}$ Both designers have been made a UK, RSA Royal Designers for Industry (RDI). Gordon Andrews was made an honorary member for general design in 1987 and Marc Newson was made a RDI in 2006.

${ }^{89}$ B. Galligan, W. Roberts, and G Trifiletti, Australians and Globalisation: The Experience of Two Centuries, Cambridge: Cambridge University Press, 2001, p. 138.

${ }^{90}$ Nicholls, op. cit, p. 3.

${ }^{91}$ J. Craik, L. McAllister, \& G. Davis, 'Paradoxes and Contradictions in Government Approaches to Contemporary Cultural Policy: An Australian Perspective', International Journal of Cultural Policy, vol. 9, no. 1, 2003, p. 21.

${ }^{92}$ Jackson, (2006) op. cit, p. 255.

${ }^{93}$ Maynard, op. cit., Whitehouse, op. cit.

${ }^{94}$ R. Waterhouse, The Vision Splendid: A Social and Cultural History of Rural Australia, Fremantle Arts Centre Press, 2005, p. 274. 